\title{
レシーバー関数による東北日本弧の 地款・最上部マントル速度構造の推定
}

\section{Seismic Velocity Structure of the Crust and Uppermost Mantle beneath the Northeastern Japan Arc Estimated from Receiver Functions}

\author{
Yasue Soda, Toru Matsuzawa and Akira Hasegawa \\ Research Center for Prediction of Earthquakes and Volcanic Eruptions, \\ Graduate School of Science, Tohoku University, Aoba-ku, Sendai 980-8578, Japan
}

(Received May 7, 2001; Accepted September 17, 2001)

\begin{abstract}
We estimated the seismic velocity structure of the crust and uppermost mantle beneath the northeastern Japan arc using receiver functions. Since the conventional methods for analyzing the receiver functions have several problems, we improved the methods at first. 1) Although the water level method is frequently used in stabilizing the receiver functions, this method sometimes distorts the results considerably. Moreover there are no objective criteria in selecting the most appropriate water level. In this paper, we adopt smoothing of spectra using Hanning window for the stabilization because its meaning in the frequency-domain FFT analysis is clearer than the water level method and it causes less distortion of the receiver functions. 2) Time-domain stacking of the receiver functions is very popular but this procedure needs many waveforms to obtain good S/N. Moreover, the result obtained from this procedure is not the least-squares estimation. We formulate a new frequencydomain stacking procedure that corresponds to the weighted least-squares method and can treat the data properly according to their S/N. 3) Usually, the structure estimated from the receiver-function analysis has poor uniqueness even if the minimum-roughness constraint is adopted. We have developed an inversion method in which the solution is constrained to the initial model structure. If we use a proper initial structure which satisfies the direct wave travel times, it is expected that the structure estimated from the inversion also satisfies the travel times to a considerable extent. We applied these methods to the seismograms recorded at broadband stations in the northeastern Japan arc in order to estimate the structure beneath the stations. The main results are as follows: 1) In the east of the northeastern Japan arc, the Conrad discontinuity is identified and its depth is consistent with the result of Zhao et al. (1990). 2) There exist low velocity (LV) zones in the lower crust beneath stations HSK and DIT; the LV zones are located just below the Conrad beneath HSK, and just above the Moho beneath DIT. 3) There exists a LV zone in the uppermost mantle beneath station KGJ. This result is consistent with Nakajima et al. (2001b) but our result indicates that the LV zone is as thin as around $5 \mathrm{~km}$. 4) Beneath station HOJ the velocity in the surface layer is extremely low.
\end{abstract}

Key words: Receiver function, Seismic velocity structure, Northeastern Japan arc.

\section{§1.はじめに}

1980 年代以降, 計算機の性能の向上とトモグラ フィー手法の改良により, 東北日本弧の詳細な地震波速 度構造が明らかになってきた [例えば, Hasemi et al.

* $\mathbf{T} 980-8578$ 仙台市青葉区荒巻字青葉

†現所属: シュルンベルジェ株式会社 于229-0006 神奈川県相模原市淵野辺 2-2-1
(1984), 中島・他 (2001), Nakajima et al. (2001b, c), 小 原・他 (1986), Zhao et al. (1992)]. しかし，これらの研 究のほとんどはデータとして初動の到達時刻のみを用い ており，このような手法では境界面の深さと地震波速度 の間でトレードオフが生じてしまう。境界面の深さ分布 を推定するには, 直達波だけでなく, 反射波や変換波の デー夕も用いた方が有利であるが，後続波の到達時刻を 
精度良く読み取ることは一般にむずかしい，一方，波形 そのあのをデータとしてインバージョンを行えば, 後続 波の到達時刻の読み取りにおける任意性の問題は解決で き，かつ振幅情報む利用することになるので, 境界面で のインピーダンスコントラストも同時に推定できる.

しかしながら, 波形デー夕を用いる場合, 震源時間関 数の不確定性が問題となる。この問題を解決するための 手法として, Langston (1979) により提唱されたレシー バー関数解析がある。これは，地震波形の水平動成分を 上下動成分でデコンボリューションすることにより震源 過程の影響を除去し, 観測点付近の構造のレスポンスを 得る手法である．地震波形データがデジタルで記録され るようになり，波形の処理が容易になったことと，単一 観測点データでも解析を行うことができるという利点が あるため，世界中でこのレシーバー関数による解析が広 く行われるようになった [例えば, Abers (1998), Li et al. (2000), Peng and Humphreys (1998), Shibutani et al. (1996), Zhu and Kanamori (2000)].

しかし，通常用いられる解析方法 [例えば，Ammon et al. (1990), Cassidy (1992), Owens et al. (1984)] には 下記に述べるようないくつかの問題点がある．1）レ シーバー関数を求めるためのデコンボリューション計算 における不安定性を解決するためにウォーターレベル法 [Clayton and Wiggins (1976)] が通常用いられている が，この手法ではレシーバー関数を歪ませてしまう場合 がある．2）個々の地震波形からレシーバー関数を求め た後, 時間領域でスタックを行うことが一般的である が，この方法で得られる推定值は最小自乗解となってお らず，S/Nの悪いデータの影響を強く受けてしまう. 3）レシーバー関数は時間情報として $\mathrm{P}$ 波到着時刻から の相対時刻しか保持されていないため，推定される速度 構造が初動の絶対走時を満足している保証はない，本論 文では,これらの問題点に対する改良法を示し，それら を用いて東北日本弧の地震波速度構造の推定を試みた。

\section{§2. 解析手法}

\section{1 レシーバー関数}

地震動の動径 (radial) 方向の水平動成分 $R(t)$ と上下動 成分 $Z(t)$ は時間領域では

$$
\begin{aligned}
& R(t)=E_{R}(t) * I(t) * S(t) \\
& Z(t)=E_{Z}(t) * I(t) * S(t)
\end{aligned}
$$

のように表せる。 ただし， $E_{R}(t)$ と $E_{Z}(t)$ はそれぞれ動径 方向と上下方向の構造のインパルスレスポンス, $I(t)$ は 計器のインパルスレスポンス, $S(t)$ は震源時間関数であ り，*はコンボリューションを示す．この $R(t)$ を $Z(t)$ で デコンボリューションしたものがレシーバー関数であ
る. デコンボリューションには時間領域で行う方法と周 波数領域で行う方法の両方があるが，ここでは周波数領 域でのデコンボリューションを考えることにする．時間 領域におけるコンボリューションとデコンボリューショ ンは, それぞれ周波数領域での掛け算と割り算に対応す る. $R(t)$ と $Z(t)$ のフーリエ変換を $R(\omega)$ と $Z(\omega)$ と表す 之, レシーバー関数のフーリエ変換は

$$
H(\omega) \equiv R(\omega) / Z(\omega)=E_{R}(\omega) / E_{Z}(\omega)
$$

となる。ここで $\omega$ は角周波数を表し， $E_{R}(\omega)$ と $E_{Z}(\omega)$ は 構造の周波数応答とする. $H(\omega)$ にフーリエ逆変換を行 い，時間領域にしたものがレシーバー関数である．ただ し，高周波側はノイズが大きいので，実際に計算する際 には (3) 式ではなく，位相を変化させずに高周波域を低 減させるガウシアンフィルター $g(\omega)$ を掛け,

$$
H(\omega) \equiv[R(\omega) / Z(\omega)] \cdot g(\omega)
$$

を計算するのが一般的である．ここで，

$$
g(\omega)=\exp \left(-\omega^{2} / 4 a^{2}\right)
$$

である ( $a$ は定数).

水平動と上下動での計器のインパルスレスポンスが等 しいとき，(3) 式のように構造に関する情報のみが残さ れ，震源の影響を取り除くことができる（計器のレスポ ンスが異なっている場合でも，それを補正することによ り同様の結果が得られる)。このようにレシーバー関数 は，上下動のレスポンスと水平動のレスポンスのスペク トル比を時間領域に変換したものであると考えることが できる.

Langston (1979) がこの手法を提唱したときは，P 波 のウェーブレットの上下動成分が近似的に震源時間関数 を表していると考え，水平動を上下動でデコンボリュー ションすることにより, 構造のインパルスレスポンスの 水平動成分のみが残ると考えられていた。 しかしなが ら, 地下の構造が水平成層構造である場合, $\mathrm{P}$ 波の多重 反射による波は直達 $\mathrm{P}$ 波と同じ入射角で地表に到達す るので, 振動方向が直達 $\mathrm{P}$ 波と同じになり, 複雑な震源 時間関数の波が入射したのとほぼ等価となる。このた め, 震源時間関数の影響が除去されるのと同様に, $\mathrm{P}$ 波 の多重反射の影響むかなり除去されることになる。した がって実際に得られるレシーバー関数では，構造のレス ポンスのうち P 波の多重反射による成分が弱められ, Ps 変換波などの最終的に S 波として地表に到達する波の 寄与が強調されている [Ammon (1991)]. このように, レシーバー関数ではもともとの波形にあった $\mathrm{P}$ 波の多 重反射の振幅が小さくなるため, 個々の位相之構造の境 界面との対応がつけやすくなるという利点がある. 


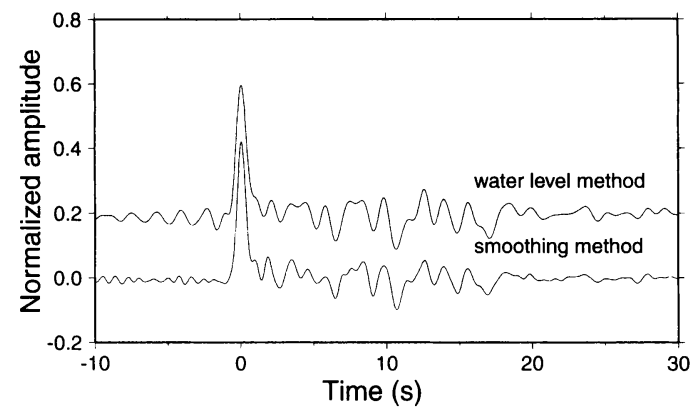

Fig. 1. Receiver functions at DIT from an event on March 29, 1998 (see Table 1). Top trace is the receiver function calculated using the water level method (water level $c=0.01$ ); bottom trace is the receiver function obtained from the smoothing method with the Hanning window. Note that the top trace has considerable fluctuation in the time range from -10 to 0 seconds.

\section{2 これまでの手法の問題点と本解析における改良} 点

\subsection{1 レシーバー関数の計算方法}

周波数領域でデコンボリューションを計算する場合に は, 割り算を行うため, 分母が小さい值となる場合は解 が不安定になる. 周波数領域でのレシーバー関数の分母 は, (3) 式より上下動成分のスペクトルである. したがっ て，上下動成分のスペクトルがある帯域で著しく小さな 值（ホール）をむつ場合, レシーバー関数は不安定とな る.スペクトルにホールを生じる原因としては, 信号と してそのような性質をもつ場合と, 有限長のデー夕を処 理（ウィンドー操作）するために人工的に生じてしまう 場合がある (後述).このようなホールの存在に伴う計算 の不安定性に対する解決策として, 通常, ウォーターレ ベル法が用いられる. 以下でまずこの方法について説明 する.

レシーバー関数のフーリエスペクトルの分母と分子 に, 上下動成分のスペクトルの複素共役 $Z(\omega)^{*}$ を掛ける Ł

$H(\omega)=R(\omega) \cdot Z(\omega)^{*} / Z(\omega) \cdot Z(\omega)^{*}$

となる.これを計算する代わりに，

$$
H(\omega)=R(\omega) \cdot Z(\omega)^{*} / \phi(\omega)
$$

を計算するのが，ウォーターレベル法である，ただし，

$$
\phi(\omega)=\max \left[Z(\omega) \cdot Z(\omega)^{*}, C\right]
$$

$C=c \cdot z_{\max }, c$ : 定数 $\left(\right.$ ウォーターレベル), $z_{\max }: Z(\omega) \cdot Z(\omega)^{*}$ の最大値,

$$
\max [A, B]=\left\{\begin{array}{l}
A(A \geq B) \\
B(B \geq A)
\end{array}\right.
$$

とする. (6) 式のように変形することで, レシーバー関数
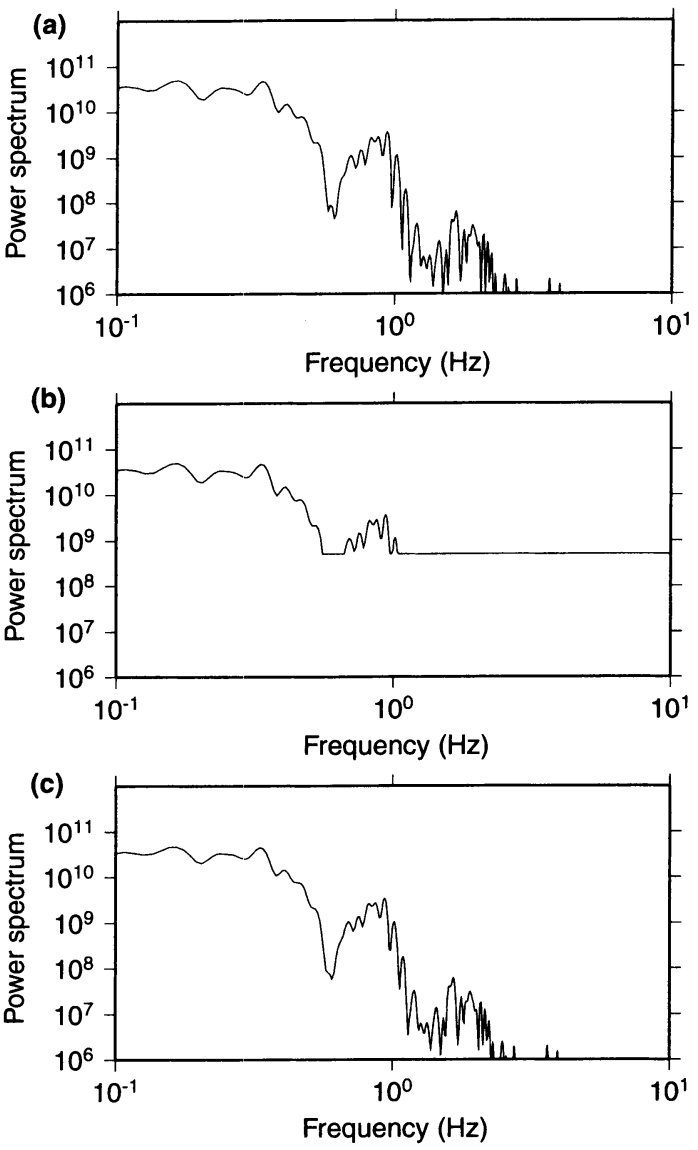

Fig. 2. Power spectra of vertical component seismogram around $\mathrm{P}$-wave arrival observed at DIT from the event on March 29, 1998. The receiver functions calculated from these spectra are shown in Fig. 1. (a) Power spectrum calculated by using FFT. (b) Spectrum obtained from equation (8) using the water level method. (c) Smoothed power spectrum obtained by applying Hanning window.

のフーリエスペクトルの分母は上下動成分のパワースペ クトルとなる.つまり,このパワースペクトルが, 閾値 $C$ よりも大きくなる周波数についてはパワースペクトル の値をそのまま用い, 閾値 $C$ より小さくなる周波数では 閾値 $C$ をパワースペクトルの值の代わりに使用して計 算する方法がウォーターレベル法である.この方法で は, 振幅の情報のみとなった分母を操作するので, 位相 の情報は保存される，通常はウォーターレベルとして， $c=0.01$ 程度の值を採用することが多い［例えば, Langston (1979), Owens et al. (1984)] が, c が小さすぎる と十分に穴埋めができない場合があり, 一方で $c$ が大き すぎる場合にはレシーバー関数の時間原点の前に大きな 


\section{しみ出しが生じてしまう.}

高周波数側にあるホールが原因でレシーバー関数が不 安定になる場合, 実際には高周波域を減衰させるガウシ アンフィルターを掛けているので, ウォーターレベル法 による影響は低減される. しかし低周波数側にあるホー ルが原因となる場合, 波のしみ出しは大きくなってしま う. その例を Fig. 1 と Fig. 2(b) に示す（データの詳細に ついては, 2.3 節を参照). ウォーターレベル法を使った 例ではレシーバー関数の時間原点の前に人工的な振動が 現れている.これは, 低周波側のホールを極端に穴埋め してしまったため生じた現象である.この例では, $c$ の 值を小さくすればウォーターレベル法でも波のしみ出し を小さくできるが，その $c$ の值が別の波形でも最適であ ると限らないため, 上記のような問題を避けるには波形 毎に $c$ の值を試行錯誤的に決定せねばならない.

本解析では, このようなウォーターレベル法の問題点 を克服するため, レシーバー関数のフーリエスペクトル を平滑化法により安定化させることにした.

スペクトル解析においては見かけのホールがしばしば 出現し，特にこれはFFTにおいて顕著である.この人 工的なホールが生成する原因としては以下の二つが考え られる.

（1）スペクトルの漏れの影響: 通常のスペクトル解析 で得られる結果は, 真のスペクトルそのものではなく, 解析に使用したデータウィンドーのフーリエスペクトル と真のスペクトルとのコンボリューションとなってい る. 言い換えれば, 得られたスペクトルには, 別の周波 数からの影響（いわゆる「スペクトルの漏れ (spectral leakage)」) が常に含まれていることになる [例えば, 大 崎 (1976)].このスペクトルの漏れが真のスペクトルに 上乗した結果, 見かけのホールが生じてしまうことがあ る.

(2) ノイズの影響：ノイズが定常エルゴード的確率過 程に従う場合, FFT で推定されたノイズのパワースペ クトルの推定誤差は $100 \%$ となる [日野 (1977)].つま り, パワースペクトルの大きさそのものと同程度の誤差 が常に存在するため, 得られたスペクトルは激しく振動 する. 地震波形の場合は確率過程に従うわけではない が，それに上乗するノイズについては上記の問題があ る.このため, $\mathrm{S} / \mathrm{N}$ の悪い帯域について解析すると, あ る周波数でたまたま信号とノイズが同程度の振幅で逆位 相であれば，見かけのホールをつくってしまう.

$\mathrm{S} / \mathrm{N}$ の良い帯域のみを取り扱う場合には, 人工的な ホールを作る主たる原因は, 上記の (1) で示したスペク トルの漏れの影響である. そのホールの深さはノイズの わずかな違いで変化するため, FFT の出力に対してア
ンサンブル平均処理を行えば, 見かけのホールの深さを 軽減できることになる. 実際にはアンサンブル平均を求 めることは困難なことが多いため, FFTによるパワー スペクトルやクロススペクトルの推定においては平滑化 処理を行うのが普通である [日野(1977)].

(6) 式において，分母は上下動成分のパワースペクト ル, 分子は上下動成分と水平動成分のクロススペクトル となっており, それぞれを平滑化することはFFT の結 果の処理としては極めて妥当であると考えられる. (6) 式の分母と分子を平滑化してレシーバー関数を推定した 例を Fig. 1 に，またそのときの上下動成分のパワースペ クトルを Fig. 2(c) に示す. 平滑化には通常用いられる八 ニングウィンドーを使用した. 平滑化は, 1 回 (1 サイク ル）のみ行い, 平滑化の結果はある周波数とその両隣の 周波数の計 3 点における值の重み付き平均となって いる.

Fig. 1 で, ウォーターレベル法では時間原点より前に 波がしみ出しているのが顕著に見られるが, 平滑化法で はそのようなことはない. ウォーターレベル法は, トラ フ状に幅広くスペクトルの落ち込みがある場合と, 単な るスパイク状のホールを区別せずに埋めてしまう (Fig. 2(b)). これに対して, 平滑化法では穴埋めが顕著となる のはスパイク状のホールが現れた場合に限られ, トラフ 状の場合には極端な穴埋めはしない (Fig. 2(c)). ウィン ドー操作に伴う人工的なホールはほとんどの場合スパイ ク状であるため, スパイク状のホールのみを穴埋めする 平滑化法の方がスペクトルの推定には望ましいと考えら れる.

もともとウォーターレベル法は, 線形応答システムに おいて, 出力波形を入力波形でデコンボリューションし て応答関数を推定する際に用いられる手法である.この 場合, 共鳴周波数でないかぎり, ある帯域で入力の振幅 が極めて小さければ当然その帯域における出力も極めて 小さくなる（入力と出力のホールの位置が同じ）ことが 保証されているので, 小さなウォーターレベルを用いる だけで応答関数を安定化させることができる. 一方, レ シーバー関数の場合は, (3) 式の分母と分子が入出力の 関係にないため, 分母の振幅が小さい帯域において分子 あ小さいという保証はなく, ウォーターレベルをかなり 大きくしないと安定化できないことがある. 一方, レ シーバー関数におけるこのような分子と分母のホールの 位置の違いは, 構造の影響によって形成されている場合 があり，このようなホールを大きなウォーターレベルを 用いて安易に埋めてしまうと, 構造の重要な情報を捨て てしまうことになる。

また線形応答システムの解析の場合は, 波の振動が十 
分収まるまでデータウィンドーを広くとって解析するこ とが普通であるため, データウィンドーによるスペクト ルの漏れの影響は少なく，人工的なホールが形成される 危険性は低い.これに対してレシーバー関数の場合には $\mathrm{P}$ 波およびそのコーダ部分を使うという手法の制約か ら，振動が十分収まるところまでウィンドウを広げるこ とができず（全波形を使うと slowness の異なる波が含 まれてしまう)，データウィンドーの影響による見かけ のホールが生成してしまう危険性がつねにある.このよ うな人工的なホールの場合も，(3) 式の分子と分母で同 じ位置にホールが存在することは保証されないので, ウォーターレベル法で安定化させるのは困難となる.

実際の解析ではガウシアンフィルターを用いて高周波 成分を除去しているため, 高周波側にホールが存在して いた場合, ウォーターレベル法と平滑化法とでほぼ同じ 結果が得られる. しかし, ウォーターレベル法では, 閾 值を決める際に任意性があり, また地震波のスペクトル は一般に高周波ほど振幅が小さいため, ウォーターレベ ル法を用いると Fig. 2(b) で示したように高周波側の振 幅の情報が極端に失われてしまうことになり，解析でき る帯域が狭められてしまう。極端なホールの場合は平滑 化法では十分な穴埋めができないことがあるが，これは 致命的な欠点とはならない.なぜなら，人工的なホール は信号やノイズのわずかな違いによって出現位置や深さ が異なるので, 後述の周波数領域におけるスタックを行 うことによりさらに穴埋めすることができるためであ る.

以上見てきたように，ウォーターレベル法よりも平滑 化法の方が優れていると考えられるので, 本解析では,

平滑化法を用いて計算したレシーバー関数を用いること にする.

なお, 上述のとおり，見かけのホールは，ウィンドウ の形状やノイズの状況に極めて敏感であるため，様々な 形状のデータウィンドウを用いて解析した結果の平均值 を用いれば，信頼度の高いスペクトルが得られると期待 される.このような考えに基づいてスペクトル解析を行 うのが multiple-taper 法 [例えば, Park and Levin (2000)] である. 単一の波形からのFFT によるスペク トル推定法としては, multiple-taper 法が現時点で最良 であると考えられるが, 計算手順が複雑となるのが欠点 である. 本解析では複数の波形デー夕も利用できるた め, multiple-taper 法を用いずとも, 単純な平滑法で十 分であると判断した.

\subsection{2 レシーバー関数のスタッキング}

レシーバー関数を用いた解析では, $\mathrm{S} / \mathrm{N}$ をあげるため 時間領域でレシーバー関数をスタックすることがよく行
われており，これは周波数領域で言えば (3) 式をそのま まスタックすることに相当する. しかしながら，(3) 式の ようなスペクトル比の $\mathrm{S} / \mathrm{N}$ を向上させたい場合には, (6) 式の分子と分母をそれぞれスタックするのが本来正 しいやり方である [例えば, Jordan and Sipkin (1977)]. 本節ではこの周波数領域におけるスタックの意味を明確 にし，本解析で使用した重み付きスタックの説明を する.

ある周波数 $\omega$ に注目し, $N$ 組の地震波形データから 一つのレシーバー関数のフーリエスペクトル $H(\omega)$ を推 定する場合, これは各地震波形データから

$$
R^{i}(\omega)=Z^{i}(\omega) \cdot H(\omega)+e^{i}(\omega) \quad(i=1 \sim N)
$$

という観測方程式を作って $H(\omega)$ について解くことに相 当する. ここで, $R^{i}(\omega)$ と $Z^{i}(\omega)$ を $i$ 番目の地震波形デー 夕の動径成分と上下成分のスペクトル, $e^{i}(\omega)$ をノイズと する.これを行列表記すると

$$
\mathbf{R}=\mathbf{Z} \cdot H(\omega)+\mathbf{e}
$$

となる. ただし, $\mathbf{R}, \mathbf{Z}, \mathbf{e}$ は $N$ 行 1 列の行列であり, $\mathbf{R}=$ $\left(R^{1}(\omega), R^{2}(\omega), \cdots, R^{N}(\omega)\right)^{t}, \mathbf{Z}=\left(Z^{1}(\omega), Z^{2}(\omega), \cdots, Z^{N}(\omega)\right)^{t}$, $\mathbf{e}=\left(e^{1}(\omega), e^{2}(\omega), \cdots, e^{N}(\omega)\right)^{t}$ とする（肩付きの $t$ は転置行 列を表す). (11) 式における最小自乗法で推定される解 $\hat{H}(\omega)$ は

$$
\mathbf{Z}^{*} \mathbf{Z} \cdot \hat{H}(\omega)=\mathbf{Z}^{*} \mathbf{R}
$$

の正規方程式を満足する解となる。ここで, $\mathbf{Z}^{*}$ は $\mathbf{Z}$ の随 伴行列（転置行列の複素共役）を表す. (12) 式を書き下 すと,

$$
\left[\sum_{i}^{N} Z^{i}(\omega)^{*} \cdot Z^{i}(\omega)\right] \cdot \hat{H}(\omega)=\left[\sum_{i}^{N} Z^{i}(\omega)^{*} \cdot R^{i}(\omega)\right]
$$

となり, 結局,

$$
\hat{H}(\omega)=\left[\sum_{i}^{N} R^{i}(\omega) \cdot Z^{i}(\omega)^{*}\right] /\left[\sum_{i}^{N} Z^{i}(\omega) \cdot Z^{i}(\omega)^{*}\right]
$$

と表せる. つまり最小自乗法的にレシーバー関数のフー リエスペクトルを求めるには，(6)式における分母のパ ワースペクトルと分子のクロススペクトルをそれぞれス タックしてから比をとれば良いことになる。

スペクトルにホールが残っている場合, 個々のレシー バー関数では時間領域でモノクロームな振動が現れてし まい，これを時間領域のスタックで除去するには, 多数 の波形データが必要である.これに対して(14)式のス タックでは, ホールの状況がスペクトルによって異なっ ていれば数個のスタックでこのホールの影響を軽減でき るという利点がある.

しかし，(14) 式は重み付き最小自乗法とはなっておら ず，この方法のままではノイズの大きいデー夕の影響を 強く受けてしまう. また (11) 式で示した観測方程式は動 径成分のみにノイズが存在している場合の式であり,こ 
の式が成立するためには上下成分が動径成分に比べて $\mathrm{S} / \mathrm{N}$ が良いことが前提となる。レシーバー関数の解析は 遠地地震の $\mathrm{P}$ 波初動付近について行われるため, 一般的 には上下成分の方が動径成分より信号の振幅が大きい. したがって両成分でノイズレベルが同程度であれば，上 下成分の方が動径成分に比べて $\mathrm{S} / \mathrm{N}$ が良いことが一般 的には期待できる. しかしながら，，イズの状況によっ て，たまたま上下成分の $\mathrm{S} / \mathrm{N}$ が悪いデータが含まれて いた場合には，(14) 式から得られる解は真の解と大きく 異なる危険性がある。そこで本解析では，動径成分と上 下成分の両方のノイズに依存した重み

$$
w^{i}(\omega)=1 /\left[\left|n_{R}^{i}(\omega)\right| \cdot\left|n_{Z}^{i}(\omega)\right|\right]
$$

を導入し，レシーバー関数のフーリエスペクトルを

$$
\begin{aligned}
\hat{H}(\omega)=\left[\sum_{i}^{N} w^{i}(\omega) \cdot R^{i}(\omega) \cdot Z^{i}(\omega)^{*}\right] / \\
\\
{\left[\sum_{i}^{N} w^{i}(\omega) \cdot Z^{i}(\omega) \cdot Z^{i}(\omega)^{*}\right] }
\end{aligned}
$$

の式によって推定した。なお， $\left|n_{R}^{i}(\omega)\right|$ と $\left|n_{Z}^{i}(\omega)\right|$ はそれ ぞれ動径成分と上下成分に含まれるノイズの振幅スペク トルである．地震波形中のノイズのスペクトルを直接推 定することは困難であるため，ここではノイズが定常エ ルゴード的確率過程に従うと仮定し, 直達 $\mathrm{P}$ 波の到着直 前におけるノイズのスペクトルを用いて重みを決定し た。 ノイズスペクトルにホールが生じているとその帯域 のノイズを過小評価し， S/N が高いあのとして扱ってし まうため, ノイズスペクトルの推定においても，デー夕 と同様の平滑化を行った。

この (16) 式は, (10) 式を重み付き最小自乗法で解いた のと等価な式になっている，また，上下成分のノイズも 考慮したことにより，(14)式よりも理想的なスタック法 になっていると考えられる。これまでの時間領域のス タックでは，脈動がたまたま大きい場合などのようにあ る帯域で $\mathrm{S} / \mathrm{N}$ が極めて悪ければ，その波形デー夕は全 て解析に用いることができなかったが，本手法では周波 数毎に $\mathrm{S} / \mathrm{N}$ に応じて重みを変えているので，そのよう な波形デー夕も有効利用できる。

なお本来は，(3) 式の分子と分母の両方にノイズが含 まれているという前提の元に多数のデータからスペクト ル比を推定する方法 [例えば, Pisarenko (1970)] の方 が数学的には厳密であるが, 計算が複雑になるという久 点がある．上述のように， $\mathrm{P}$ 波初動付近では動径成分よ り上下成分の方が $\mathrm{S} / \mathrm{N}$ が良い場合が普通であり，上下 成分の $\mathrm{S} / \mathrm{N}$ が動径成分より悪いデータしか利用できな いという特殊な状況でなければ，(16) 式のような単純な 推定法で十分であると考えられる。

\subsection{3 レシーバー関数を用いた速度構造のインバー ジョン}

インバージョンには, Ammon et al. (1990) の手法を 改良して用いた。この手法では, 各層の厚さと $V_{\mathrm{p}} / V_{\mathrm{s}}$ を 固定し, 線形化法を用いたイタレーションにより各層の $\mathrm{S}$ 波速度を解として求めている（ただし後述のとおり, 一回のイタレーションでは通常の線形化法のように S 波速度の変分を解いているのではなく, $\mathrm{S}$ 波速度そのも のを解いていることに注意).レシーバー関数のイン バージョンでは，ガウシアンフィルターを用いた狭帯域 の解析を行っているので，実際に独立なデー夕数は見か けのデータサンプル数よりあ減少する．そのため真に独 立なデー夕数がパラメー夕数と同等またはそれ以下と なって解が不安定となることが多い。この問題を解決す るため, Ammon et al. (1990) の手法では構造のラフネ スを最小にする拘束を与えている.

しかし，ラフネス最小の拘束条件はモデルの短波長成 分を軽減するだけなので，デー夕に長周期のノイズが含 まれている場合, 安定した解を求めることができない. また, レシーバー関数の時間軸は直達 $\mathrm{P}$ 波との走時差で あり，絶対的な走時ではない，したがって，たとえ真に 独立なデー夕数がパラメーター数より多くかつノイズが 小さくても, 通常のレシーバー関数の解析では構造は一 意には求められず，かつ得られた構造が直達 $\mathrm{P}$ 波の絶対 走時を満足している保証はない.

そこで, 本解析では構造のラフネスに関する拘束条件 の代わりに初期モデルに拘束する条件を導入することに した。これまでの研究により, 地殸の平均的な速度構造 は求められており，それらを初期モデルとして用いてそ れに拘束させることにより, 直達 $\mathrm{P}$ 波の絶対的な走時を ほぼ満足する解が得られると期待される。これは過去の 研究で求められた大局的な構造を先験的情報として用い たベイズ推定を行う [Jackson and Matsu'ura (1985)] ことに相当する。後述 (2.4 節) のとおり,この手法では 速度不連続の大きさを過小評価する可能性があるが， ラ フネス最小の拘束条件の場合も同様の性質があり，これ は致命的な欠点之はならないと考えられる，以下，本解 析で用いたインバージョン法について説明する.

ここでは線形化法により解を求める場合を考える．観 測波形と $(k-1)$ 回のイタレーションによって得られた モデル $\mathbf{m}_{k-1}$ から計算される理論値との差（残差ベクト ル） $\mathbf{r}$ は, $k$ 回目のイタレーションで求められる増分を $\delta \mathbf{m}_{k}$ とすると

$$
\mathbf{r} \approx \mathbf{D} \cdot \delta \mathbf{m}_{k}=\mathbf{D} \cdot\left(\mathbf{m}_{k}-\mathbf{m}_{k-1}\right)
$$

となり,これを変形して

$$
\mathbf{D} \cdot \mathbf{m}_{k} \approx \mathbf{r}+\mathbf{D} \cdot \mathbf{m}_{k-1}
$$


が得られる [Ammon et al. (1990)]. ここで, $\mathbf{m}_{k}$ は $k$ 回 目のイタレーション後に求められるモデル（各層の $\mathrm{S}$ 波 速度), $\mathbf{D}$ は係数行列であり, 各成分はモデル $\mathbf{m}_{k-1}$ から 計算されるレシーバー関数の偏微分係数となる.この偏 微分係数は解析的には求められないので, 数值的に差分 計算により求める [Randall (1989)].

また，初期モデルに拘束する条件は

$$
\beta \cdot \mathbf{I} \cdot\left(\mathbf{m}_{k}-\mathbf{m}_{0}\right) \approx \mathbf{0}
$$

と書ける. ここで, $\beta$ は初期モデルへの拘束の強さを表 すハイパーパラメータ, I は単位行列, $\mathbf{m}_{0}$ は初期モデル である. (17)'式と (18) 式を組み合わせると

$$
\left[\begin{array}{c}
\mathbf{D} \\
\beta \cdot \mathbf{I}
\end{array}\right] \cdot \mathbf{m}_{k} \approx\left[\begin{array}{l}
\mathbf{r}+\mathbf{D} \cdot \mathbf{m}_{k-1} \\
\beta \cdot \mathbf{I} \cdot \mathbf{m}_{0}
\end{array}\right]
$$

となり，この式から最小自乗法で $\mathbf{m}_{k}$ を推定した. $\beta$ と しては最終的に $0.3 \sim 0.6$ 程度の值を与えた(後述). この 程度の大きさの $\beta$ を用いて初期モデルへ拘束させると, イタレーションを 5 回程度行うだけで解は安定に収束 するので, イタレーションの回数は 10 回とした.

本解析に用いた初期モデルを Fig. 3 に示す. 各層の厚 さを $1 \mathrm{~km}$ とし, 層内の速度は東北大学のルーチン処理 の震源决定で用いられている 1 次元地震波速度構造モ デル [Hasegawa et al. (1978)] (以下, ルーチン構造と呼 ぶ）を基にした.このモデル（Fig. 3 の破線）は東北地 方の平均的な速度構造をよく表しており, このモデルに 拘束させることにより, 直達 $\mathrm{P}$ 波の絶対走時をほぼ満足 させる構造が得られると考えられる. 一方, この構造で は深さ $31 \mathrm{~km}$ にモ木面を表す速度不連続面があり, こ の構造をそのまま用いると, インバージョンにより得ら れるモホ面の深さが $31 \mathrm{~km}$ に拘束されやすくなるおそ れがある. そのため, ここではこのモデルを深さ $27 \mathrm{~km}$ から $37 \mathrm{~km}$ の間で補間することにより Fig. 3 の実線で 示すように速度不連続面のない滑らかな構造に変形し て，それを初期モデルとして採用することにした。 ここ で, $V_{\mathrm{p}} / V_{\mathrm{s}}$ はルーチン構造と同様に地款内で 1.71 , マン トル内で 1.78 であり, モホ面付近についてはこの值を 補間して連続的に変化させている. 密度は Ludwig et al. (1970) による S 波速度と密度の関係から換算した. インバージョンで直接的に求められるのは $\mathrm{S}$ 波速度の みであり, $\mathrm{P}$ 波速度と密度についてはイタレーション毎 に S 波速度から換算して求めた. ただし, 各層における $V_{\mathrm{p}} / V_{\mathrm{s}}$ は上記の初期構造における値のまま固定した。 ま た本解析では, 3 秒以上の長周期の波を用いているた め, 解析領域 (60 km 以浅) に入射してから時間ウィン ドウ (約 20 秒) の最後までに, 多重反射を考慮しても地 震波は最大で 10 波長程度しか伝播しない。このため地 震波の減衰は無視できると考え,ここでは $Q$ は無限大と

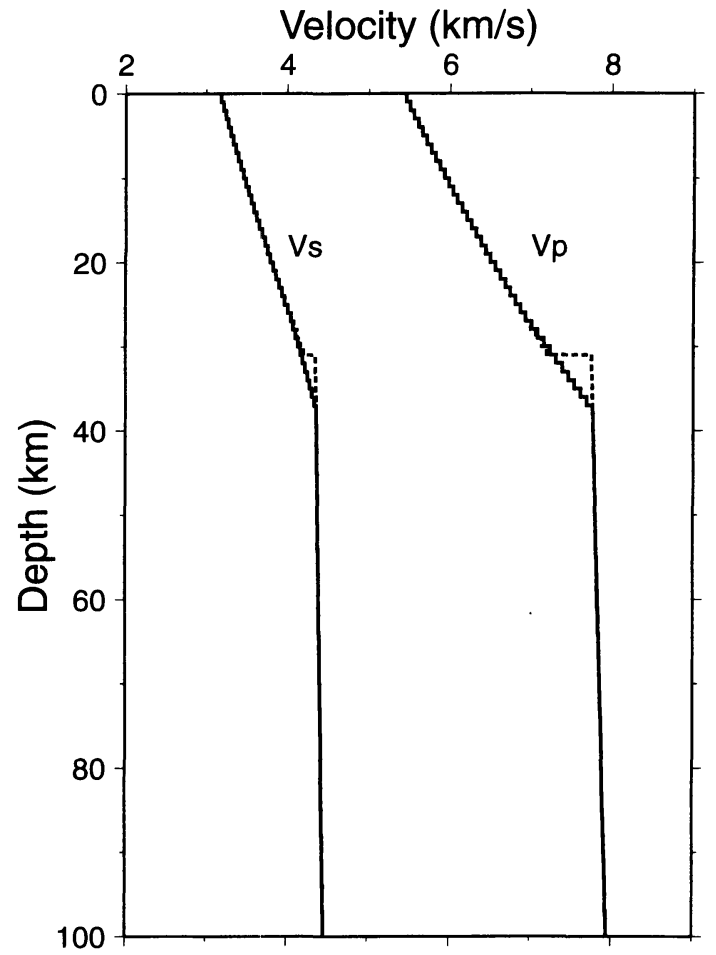

Fig. 3. The initial velocity structure model for the inversion in this study (solid line). This model is basically the same as the 'routine structure' (the structure used in Tohoku University's routine hypocenter determination) which is indicated by dashed line, but the velocity is interpolated between $27 \mathrm{~km}$ and $37 \mathrm{~km}$ depths.

した.

レシーバー関数の推定では，ノイズだけでなく 3 次元 不均質構造に伴う散乱波も誤差の原因となる。 ノイズや 散乱波の振幅が大きい波形データの場合, 動径成分之上 下成分で波形の相関が悪くなるため, 得られるレシー バー関数には時間原点の前に（たとえば, Fig. 4 の SWUや HMK のレシーバー関数について見られるよう に）大きなしみ出しが作り出される. したがって，この しみ出した部分の振幅がレシーバー関数の不確定性を表 していると考えられる. そこで, 観測波形から計算され るレシーバー関数と理論波形から計算されるレシーバー 関数との差がこのしみ出しの振幅と同程度となるように ハイパーパラメータの值 $(\beta)$ を試行錯誤的に求めた. 最 終的には, レシーバー関数の時間原点の前に信号に比べ て大きな振幅が出ている観測点 SWU と HMK につい ては, $\beta=0.6$, その他の観測点については $\beta=0.3$ が最適 であると判断し，この値をそれぞれについて使用した 


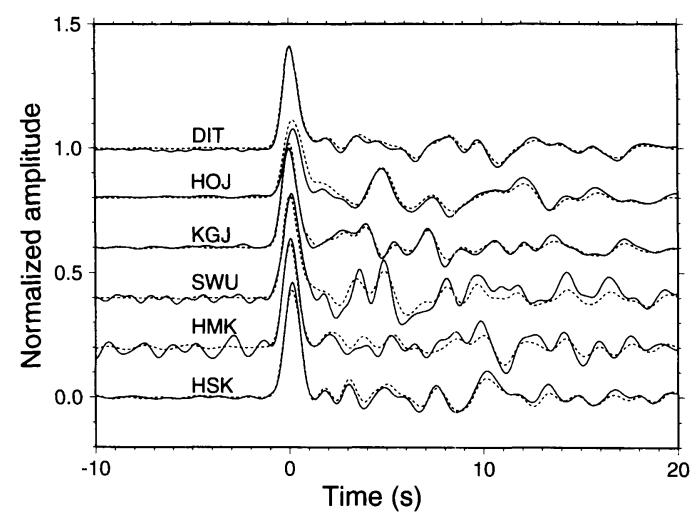

Fig. 4. Comparison of observed receiver functions (solid line) and synthetic receiver functions (dashed line) for the estimated structures beneath stations DIT, HOJ, KGJ, SWU, HMK and HSK. Each observed receiver function is obtained using the equation (16). The synthetics are calculated from the structures shown in Fig. 7 and Fig. 9. The hyperparameter $\beta$ used in the inversion is 0.6 for stations SWU and HMK, and is 0.3 for other stations.

(Fig. 4). $\beta$ の值を 0.3 から 0.6 に変化させた場合, 求め られる構造の初期構造からの偏差は約半分の大きさにな る.イタレーションの収束速度は $\beta$ が小さいほど遅くな るが， $\beta$ のオーダーが変わらなければほぼ同程度の速度 となる。

なお，ラフネス最小の拘束と初期モデルへの拘束の両 方を与えた解析も行ってみたが, 得られた結果は初期モ デルへの拘束のみを与えた場合とほ之んど変わらなかっ た.これは, むともと初期構造として滑らかな構造を置 いているため, 初期モデルへの拘束だけでもラフネスが あまり大きくならなかったためと考えられる.そのた め, 以下の解析では, 初期モデルへの拘束のみを使用し ている.

インバージョンで解くべき構造としては, 深さ 100 $\mathrm{km}$ までの厚さ $1 \mathrm{~km}$ の水平成層構造を置き, 各層の $\mathrm{S}$ 波速度を未知数とした. レシーバー関数の解析では, 浅 部構造については境界面で一回変換した波のみならず多 重反射・変換波も含めて解析対象となる（データの情報 量が多い）ため, 浅部の境界面の深さは比較的精度良く 求められる. 一方, デー夕長が短い上深部境界面につい ては一回変換した波のみが解析対象となる（デー夕の情 報量が少ない）ため, 深部の構造の推定精度は浅部に比 べて墨い. 深部について精度よく求めるためには, 多重 反射・変換波がデータに含まれるよう，デー夕長をでき るだけ長くすることが望ましい. しかし，デー夕長を長

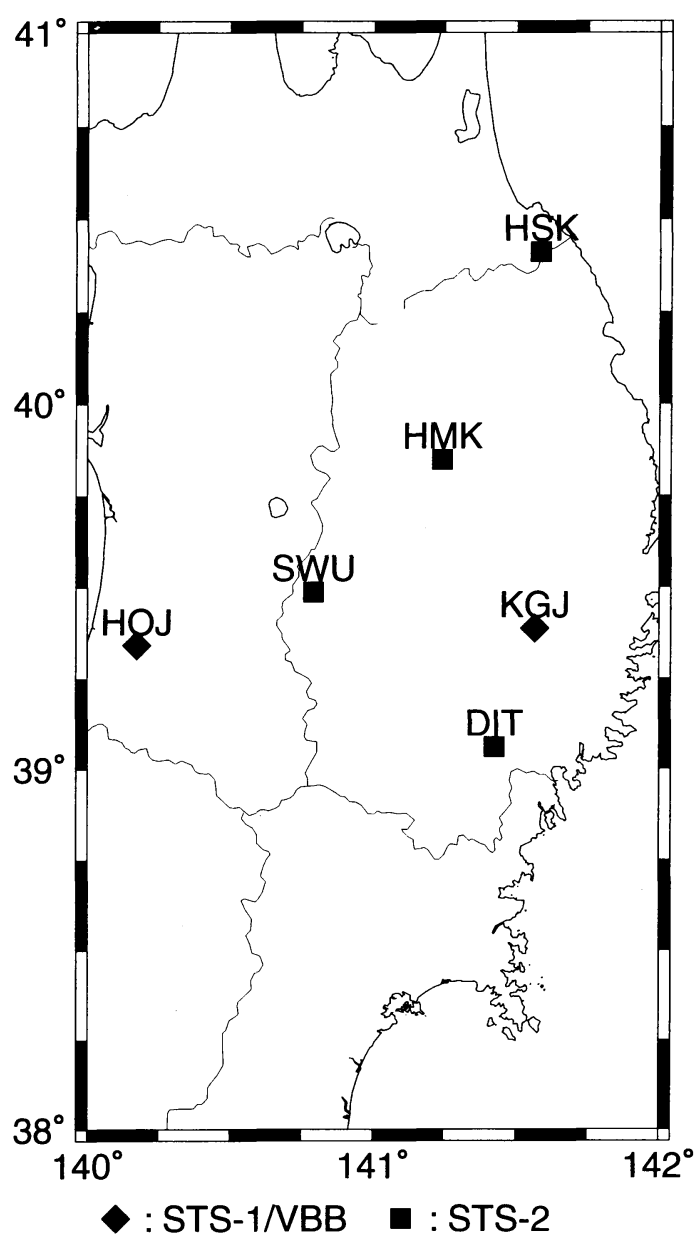

Fig. 5. Locations of broadband seismograph stations. Sensor type is indicated by different symbols (diamond: STS-1/VBB; square: STS-2).

くすればこんどはモデル化した空間よりあ深い境界面か らの変換波がデー夕に含まれてしまい, それがモデル空 間内の構造に押しつけられるため, 得られる結果には ゴーストが生じてしまう。このような問題があるため, 本解析では実効デー夕長を 20 秒とし，深さ $100 \mathrm{~km}$ ま でをモデル化してインバージョンを行うが, 結果につい ては, 深さ $60 \mathrm{~km}$ 以浅についてのみを議論の対象とす ることにした。

\section{3 データ}

データは, 東北大学地震観測網の広帯域地震計 (STS1/VBB および STS-2）が設置されている観測点 6 点で 収録された波形を用いた。これらのデー夕はERIOS シ ステム[鷹野・他, 1989] で収録されており, サンプリ ング周波数は $20 \mathrm{~Hz}$, ダイナミックレンジは 20 bit で 
Table 1. Events used in the analyses.

\begin{tabular}{|c|c|c|c|c|c|}
\hline Origin time (UT) & $\begin{array}{l}\text { Lat. } \\
\text { (deg) }\end{array}$ & $\begin{array}{l}\text { Long. } \\
\text { (deg) }\end{array}$ & $\begin{array}{l}\text { Dep. } \\
(\mathrm{km})\end{array}$ & Mb & Stations \\
\hline $94 / 07 / 16 \quad 18: 05$ & -4.62 & 125.62 & 443 & 5.8 & KGJ,SWU \\
\hline $94 / 08 / 1102: 45$ & -3.70 & 153.40 & 231 & 5.5 & SWU \\
\hline $94 / 08 / 30 \quad 19: 42$ & -6.97 & 124.11 & 596 & 5.9 & HMK,HSK,KGJ,SWU \\
\hline $94 / 09 / 28 \quad 16: 39$ & -5.79 & 110.35 & 638 & 5.9 & SWU \\
\hline $94 / 10 / 2722: 20$ & -25.78 & 179.34 & 519 & 5.9 & HMK,HOJ,KGJ,SWU \\
\hline $94 / 11 / 15$ 20:18 & -5.59 & 110.19 & 561 & 6.2 & DIT,HMK,KGJ,SWU \\
\hline $95 / 01 / 1716: 54$ & -20.83 & -179.24 & 634 & 5.9 & HOJ,SWU \\
\hline $95 / 06 / 2406: 58$ & -3.96 & 153.93 & 386 & 6.2 & DIT,HMK,HSK,KGJ,SWU \\
\hline $95 / 07 / 1501: 35$ & -19.90 & -177.55 & 358 & 5.5 & SWU \\
\hline $95 / 09 / 1412: 24$ & -17.62 & -178.97 & 533 & 5.5 & HSK,SWU \\
\hline $95 / 10 / 2919: 40$ & -21.79 & -179.39 & 618 & 5.7 & HOJ,KGJ,SWU \\
\hline $96 / 05 / 02 \quad 13: 34$ & -4.55 & 154.83 & 500 & 5.6 & DIT,HSK,KGJ,SWU \\
\hline $96 / 07 / 20 \quad 07: 41$ & -19.82 & -177.64 & 357 & 5.7 & HOJ \\
\hline $96 / 08 / 05$ 22:38 & -20.69 & -178.31 & 550 & 6.4 & DIT,HOJ,HSK \\
\hline $96 / 08 / 22 \quad 05: 35$ & -7.12 & 123.28 & 596 & 5.8 & HMK,HOJ \\
\hline $96 / 11 / 0509: 41$ & -31.16 & 180.00 & 369 & 5.9 & DIT,HMK,HOJ,HSK,SWU \\
\hline $14: 00$ & -22.26 & -179.22 & 553 & 5.2 & SWU \\
\hline /25 23:22 & -32.12 & 179.79 & 333 & 6.2 & HOJ,SWU \\
\hline$/ 1109: 55$ & -5.70 & 110.80 & 574 & 5.6 & HOJ \\
\hline $97 / 09 / 0420: 52$ & -3.48 & 151.39 & 366 & 5.1 & HOJ \\
\hline $97 / 09 / 07 \quad 12: 57$ & -6.02 & 154.46 & 421 & 5.6 & HOJ,HSK,SWU \\
\hline $97 / 09 / 26 \quad 15: 48$ & -5.39 & 128.99 & 254 & 5.8 & DIT \\
\hline 97/11/03 19:17 & -6.74 & 129.02 & 216 & 5.7 & SWU \\
\hline $97 / 12 / 26 \quad 05: 34$ & -22.34 & -179.69 & 588 & 5.3 & SWU \\
\hline 98/01/27 19:55 & -22.54 & 179.05 & 611 & 5.6 & SWU \\
\hline $98 / 03 / 29 \quad 19: 48$ & -17.55 & -179.09 & 537 & 6.5 & DIT,HOJ,HSK,KGJ,SWU \\
\hline $98 / 04 / 2023: 34$ & -39.04 & 175.12 & 251 & 5.1 & HOJ \\
\hline $98 / 04 / 28 \quad 15: 44$ & -21.97 & -179.61 & 608 & 5.3 & HOJ \\
\hline $98 / 05 / 1602: 22$ & -22.23 & -179.52 & 586 & 6.1 & DIT,HMK,HOJ,HSK,KGJ,SWU \\
\hline $98 / 05 / 23 \quad 17: 44$ & 8.14 & 123.73 & 658 & 5.9 & HOJ,SWU \\
\hline
\end{tabular}

ある. 観測点の位置を Fig. 5 に示す.これらの観測点で 1994 年 7 月から 1998 年 5 月に観測されたマグニ チュード 5 以上の地震のうち, 地表反射波等の遠方起源 の後続波による影響を避け，かつなるべく slowness が 同程度となるようにするため, 震央距離 $30^{\circ}$ から $90^{\circ}$, 震源の深さ $200 \mathrm{~km}$ 以深の遠地地震 30 個をPDE カ夕 ログから選び出し, その地震波形を用いた. 解析では $\mathrm{S} / \mathrm{N}$ に応じて重みがかかっているため, 実際には観測さ れた全波形を用いても結果はほとんど変わらないが,こ こでは有効デー夕数を明確にするために比較的 $\mathrm{S} / \mathrm{N}$ の 良い波形データ 71 トレースのみを用いた。この 71 ト レース中の観測点毎の内訳は, DITが 8 トレース, HMK が 7 , HOJ が 16, HSK が 9, KGJ が 9, SWUが 22 である. 各観測点について使用した地震のリストを Table 1 に示す.これらの波形データについて, P 波初 動の 2 秒前から 24 秒間のデータを切り出し, 最初と最 後の 2 秒間について $\cos$ 型のテーパーをかけた. さらに その後ろに 78.4 秒分のゼロパディングを行い, 総計 102.4 秒 (2048 サンプル) のデータを解析した. デコン ボリューションを行った波形は尾を長くひくことが多 く, FFT 解析ではこの影響が前方にまわりこんでしま う。このまわりこみの影響を極力避けるため，ここでは ゼロパディングを長くとっている.レシーバー関数を計 算する際には，この波形を FFT し，2.2.1 節で述べた平 滑化を行った後，(16) 式のスタックを行い，このスタッ ク波形にガウシアンフィルターを掛けた. 使用したガウ

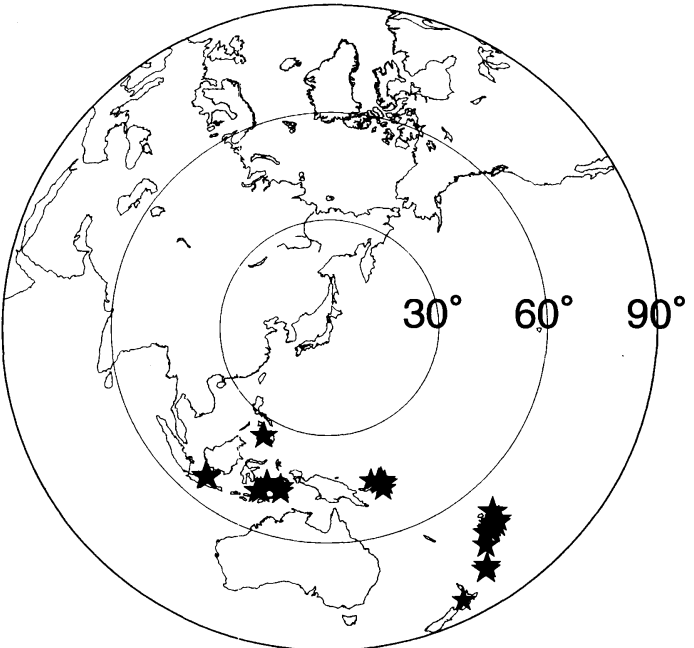

Fig. 6. Epicenter distribution of events used in this study (after PDE catalogue). The hypocenter parameters are shown in Table 1. The map is drawn using azimuthal equidistant projection. Distance from the center of the broadband seismograph stations is indicated by a circle.

シアンフィルターは(5) 式で $a=2$ としたフィルター $(0.37 \mathrm{~Hz}$ で $-3 \mathrm{~dB}$ のローパスフィルター) である.

使用する地震波形は, 観測点から見た震央の方位角 (back azimuth) が $135^{\circ}$ から $225^{\circ}$ の範囲であったため, 地震波はすべてほぼ南 (Fig. 6) から到来すると考え, 本 解析では震央によって領域分けせずに, 観測点ごとにス タックを行った. インバージョンにおいては, 各観測点 ごとに，使用した波形の直達 $\mathrm{P}$ 波の slowness の平均值 を求め, その值を用いて理論的なレシーバ関数を計算し た. なお, slownessの值については, iasp91 の走時表 [Kennett, 1991] から求めた. 用いたデータの slowness の最小値は $5.37 \mathrm{~s} / \mathrm{deg}$, 最大值は $7.83 \mathrm{~s} / \mathrm{deg}$ である.

\section{4 インバージョンの推定精度の評価}

このインバージョンによって得られる構造の推定精度 を評価するために, 簡単なシミュレーションを行った. シミュレーションでは, 表層（厚さ $2 \mathrm{~km}$ ), 上部地壳 $(15 \mathrm{~km})$, 下部地款 $(16 \mathrm{~km})$ および上部マントル（半無 限）からなる水平成層構造のモデル（各層内では速度一 定）からの理論的なレシーバー関数を計算し，これに対 して上述のような滑らかな初期構造に拘束させたイン バージョンを行って, どの程度, 構造が復元できるかを 検証した.

シミュレーションにおいては, まず初期構造を上記の 水平成層構造 (3 層十半無限媒質) で近似した. 次に, こ 
の構造に比べて, 各層の速度が系統的に $-6 \%,-3 \%$, $+3 \%$ および+ $6 \%$ 異なる場合の計 4 種類の構造を作成 した.これらの構造から期待される理論的レシーバー関 数を計算し，これに Fig. 4 の DIT 観測点の観測值と同 程度（最大振幅の $1 / 30$ ) のランダムノイズを加え, DIT における実際の解析とまったく同じ処理を行った。この ようなシミュレーションを行ったところ，下記のような 結果が得られた。

(1) 表層の底の深さはいずれの構造を与えても完全 に再現できた. 系統的に $\pm 3 \%$ 異なる構造を与えた場合 には,コンラッド面とモホ面の深さは $1 \mathrm{~km}$ 以内の䛊差 で復元できた。 $\pm 6 \%$ 異なる構造を与えた場合には，コ ンラッド面の深さの誤差は $1 \mathrm{~km}$ だが, モホ面の深さの 誤差は $2 \mathrm{~km}$ となった. いずれの場合も, 速度ジャンプ の大きさについては, 真のジャンプの大きさの 70〜 $100 \%$ 程度で復元できた.

(2) 初期構造に拘束させているため, インバージョン により得られた各層の初期構造に対する速度偏差は真の 值よりあ系統的に小さくなるが, この傾向は深部で特に 顕著となることがわかった。 これは 2.2.3 節で述べたよ うに, データの中に含まれる深部構造に関する情報量が 浅部構造より少ないことに起因すると考えられる.

（3）短波長の凹凸（見加上の薄い高速度層や低速度 層) がインバージョンの結果には現れるが，その相対的 な速度ジャンプは $\mathrm{P}$ 波速度にして最大で $0.3 \mathrm{~km} / \mathrm{s}$ 程度 である.

本解析で用いた初期構造は東北大の震源決定に用いて いる構造を元にしており, 過去の研究 [例えば, Horiuchi et al. (1982), Research Group for Explosion Seismology (1977)] の結果を考慮すると，この構造が真の 構造と比べて浅部から深部にいたるまで系統的に 6\% あ異なっているとは考えにくい.このような判断のも と, (1) の結果より, 本解析で得られる各主要境界面の深 さの精度は $1 \mathrm{~km}$ 程度であると見積もった。 ただし(2) の問題があるため, 得られた速度の絶対值そのあのにつ いて詳細な議論は行わないことにした。 また， $\mathrm{P}$ 波速度 で $0.3 \mathrm{~km} / \mathrm{s}$ よりも小さな速度ジャンプを示す薄い高速 度層や低速度層については, (3) の結果から考えて見か けのものである可能性があるため, 基本的に議論の対象 とはしないことにした.

\section{§ 3. 結果と境論}

\section{1 観测点直下の速度構造}

各観測点直下の構造について, 走時トモグラフィーに よって東北日本弧の三次元速度構造を求めた Nakajima et al. (2001b) の結果と本解析の結果との比較を Fig. 7
に示す. 本解析では, 多重反射・変換した波もインバー ショョン解析の中に含まれているので, 得られた構造は観 測点近傍での平均的な構造を表していると考えられる. そこで比較する対象の Nakajima et al. (2001b) の構造 む, 観測点周辺 $10 \mathrm{~km}$ について平均操作を行った結果 をプロットした. なお, Nakajima et al. (2001b)では, モホ面の深さについては Nakajima et al. (2001a) と Zhao et al. (1990) の結果を, コンラッド面については Zhao et al. (1990) の結果を利用しているので, モホ面や コンラッド面について Nakajima et al. (2001b) と比較 する場合には, Nakajima et al. (2001a) と Zhao et al. (1990)を引用することにする.

以下, 本解析で得られた観測点直下の構造の特徴につ いて述べる.なお過去の研究によれば東北地方の下部地 殼と最上部マントルにおける平均的 $\mathrm{P}$ 波速度はそれぞ れ, $6.6 \mathrm{~km} / \mathrm{s}$ [Horiuchi et al. (1982)] と $7.53 \mathrm{~km} / \mathrm{s}$ [Research Group for Explosion Seismology (1977)] と いう値が得られている. そのため, 本解析の結果につい ては, 基本的に $\mathrm{P}$ 波速度で $6.5 \mathrm{~km} / \mathrm{s}$ を超える正の速度 ジャンプを示す顕著な不連続面をコンラッド面, 7.5 $\mathrm{km} / \mathrm{s}$ を超える不連続面をモ木面と解釈することにし た.

\section{(1) HSK}

地殸内では薄い表層の下に深さ $6 \mathrm{~km}$ と $17 \mathrm{~km}$ の二 箇所に正の速度ジャンプが, また深さ $22 \mathrm{~km}$ 付近に低 速度層が見られる(Fig. 7(a)). 深さ $17 \mathrm{~km}$ より下で $\mathrm{P}$ 波 速度は $6.5 \mathrm{~km} / \mathrm{s}$ を超えており, 下部地款の速度となっ ているので, この深さ $17 \mathrm{~km}$ の不連続面はコンラッド 面であると考えられる.この結果は Zhao et al. (1990) の結果と調和的である. 一方, 深さ $32 \mathrm{~km}$ に見られる正 の速度ジャンプがモホ面であると考えられるが，Zhao et al. (1990) はモ木面の深さを $34 \mathrm{~km}$ としており, 本解 析の結果では彼らの結果より $2 \mathrm{~km}$ 程度浅くなってい る. Zhao et al. (1990) では, この観測点付近は解析領域 の端に位置しているためにモ木面の決定精度が悪くなっ ていると考えられる. 一方, Zhao et al. (1990)によれ ば, この観測点が位置する海岸線付近ではモホ面が急傾 斜していると考えられるが, 本解析では水平成層構造を 仮定しているため, 本解析でも誤差が大きいと考えられ る. また, HSK では表層が低速度となっており，このよ うな場合モ木面付近から下部の構造はやや信頼度か落ち る (後述の HOJ の項参照).このような理由により, 本 解析結果むZhao et al. (1990) の結果む, モ木面の決定 精度はこの付近に関してはそれぞれの䛊差の推定值（ど ちらむ $1 \mathrm{~km}$ 程度）よりはやや悪いと考えられるので, 両者の結果は決定精度の範囲内では矛盾しないと言える 


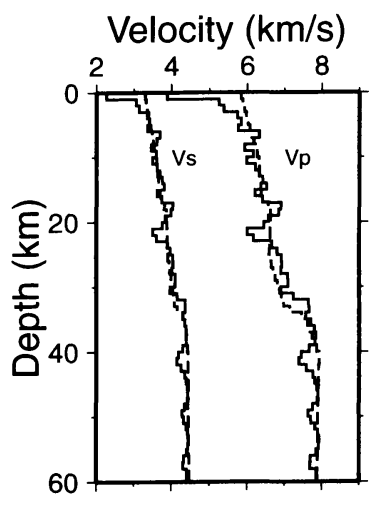

(a) HSK

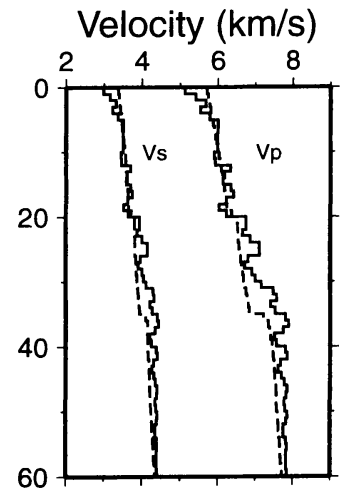

(b) HMK

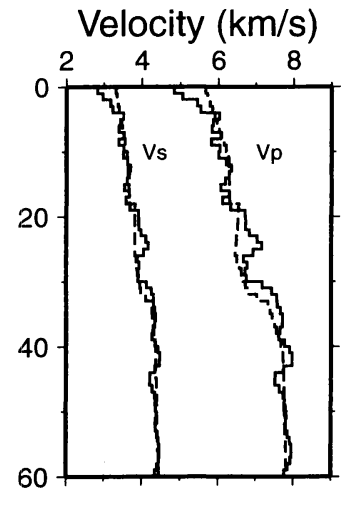

(c) DIT

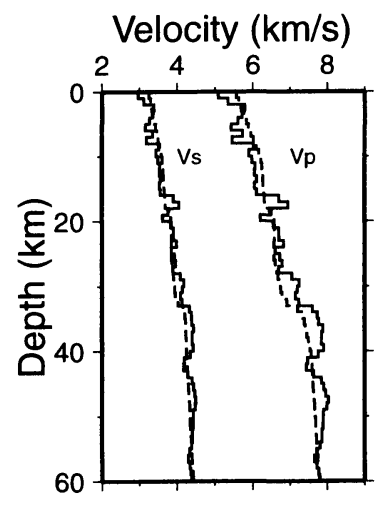

(d) KGJ

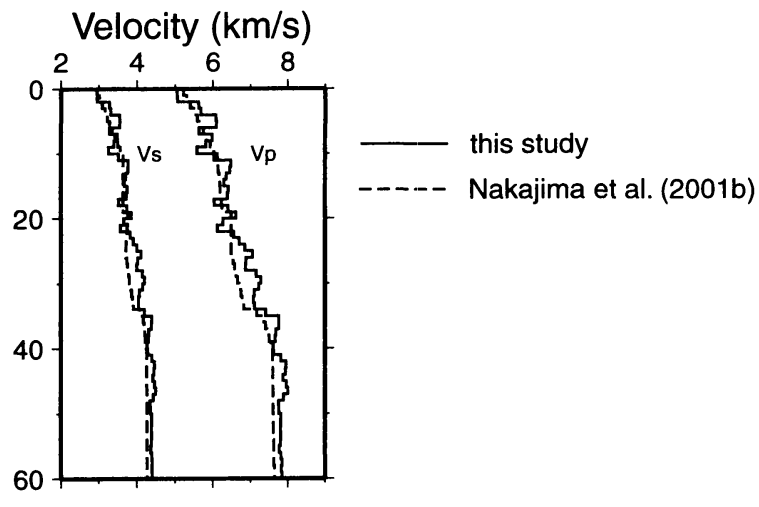

(e) SWU

Fig. 7. Velocity structures estimated from the inversions for stations (a) HSK, (b) HMK, (c) DIT, (d) KGJ, and (e) SWU. Solid and dashed lines denote the results of this study and of Nakajima et al. (2001b), respectively.

だろう. Nakajima et al. (2001b) が求めたこの付近の速 度構造は, 上部地殻ではルーチン構造より速く, 下部地 殻ではルーチン構造よりも遅くなっており，その傾向は 本解析の結果でも見られる.ただし，本解析の結果は， この観測点付近に低速度の表層が薄く存在していること を示している. また, Nakajima et al. $(2001 \mathrm{~b})$ では下部 地款内のグリッドポイントは深さ $25 \mathrm{~km}$ にしかないた め下部地款内の低速度層の深さや厚さは求められず, こ の付近の下部地款の平均的な值が得られるだけである.

これに対して, 本解析の結果は, この低速度層がコン ラッド直下の深さ $22 \mathrm{~km}$ 付近にあり, その厚さが $4 \mathrm{~km}$ 程度であることを示している.

(2) $\mathrm{HMK}$

深さ $20 \mathrm{~km}$ にコンラッド面と考えられる顕著な速度 不連続面が見られる (Fig. 7(b)). この結果は Zhao et al.
(1990) の結果より $1 \mathrm{~km}$ ほど深くなっているが, 誤差 を考慮すると, HSK と同様にほぼ一致していると考え られる. また, 深さ $31 \mathrm{~km}$ と $35 \mathrm{~km}$ にも速度ジャンプ が見られるがどちらもジャンプの大きさは小さい. 深さ $35 \mathrm{~km}$ の速度ジャンプは Zhao et al. (1990)のモホ面と 一致する. 上記の $7.5 \mathrm{~km} / \mathrm{s}$ という基準を単純に適用す ると, 本解析の結果では深さ $31 \mathrm{~km}$ の不連続面がモホ 面となる. しかし，この観測点は，レシーバー関数の時 間原点の前のしみ出しが 6 観測点中で最も大きく (Fig. 4), 3 次元的不均質による散乱波の影響が強いと考えら れる. 特に地震波速度の絶対値の信頼性は他の観測点に 比べて低いと考えられ, 深さ $31 \mathrm{~km}$ 付近の $7.5 \mathrm{~km} / \mathrm{s}$ 程 度と得られている速度の值はあまり信頼できない可能性 がある、このようなことからモホ面を深さ $35 \mathrm{~km}$ とし ても矛盾はないと考えられる. 


\section{(3) DIT}

Fig. 7(c) から, 深さ $19 \mathrm{~km}$ にコンラッド面と思われ る速度不連続面が見られる. Zhao et al. (1990) はコン ラッド面の深さを $18 \mathrm{~km}$ と求めており, 本解析の結果 とほぼ一致する。しかしモ木面の深さに関しては, 本解 析の結果では $30 \sim 31 \mathrm{~km}$ と考えられ, Zhao et al. (1990) の結果より 3〜4 km 浅くなっている. 一方, Nakajima et al. (2001b) ではモ木面の深さを 32 33 $\mathrm{km}$ としているが，これは Nakajima et al. (2001a) によ るモホ面での反射波と変換波を用いて推定した深さを滑 らかにつないだ結果に基づいている. Nakajima et al. (2001a) ではDIT 付近のモ木面の深さについては, 变換 波を用いて推定しており，この結果だけを見ると約 31 $\mathrm{km}$ となっている．変換波による推定のほうが反射波に よる推定よりも，震源決定誤差の影響を受けにくいので 精度が良いと考えられ [松澤 (1989)]，この $31 \mathrm{~km}$ とい う值は本解析の結果と一致している.

Nakajima et al. (2001b) の結果では, 下部地款で地震 波速度が遅くなっており, 逆転層を形成している。これ は, Fig.7(c) に見られるモ木面直上の厚い低速度層が原 因であると考えられる. 一方, 表層以外の上部地殼では, 本解析の結果は初期モデルより系統的に速くなってお り, Nakajima et al. (2001b) の結果之調和的な值が得ら れている.

\section{(4) KGJ}

この観測点の下の構造で特徴的なのは, 深さ $16 \mathrm{~km}$ から $18 \mathrm{~km}$ に見られる薄い高速度層である (Fig. 7(d)). これの上面は, Iwasaki et al. (1994) が見つけた反射面 の位置と一致する. モ木面の深さに関しては Nakajima et al. (2001a) および Zhao et al. (1990) と良く一致して いる.

地震波速度の值から考えて, 深さ $16 \mathrm{~km}$ の不連続面 がコンラッド面であり，そこから深さ $33 \mathrm{~km}$ にあるモ 木面までの下部地殼内に深さ $18 \mathrm{~km}$ から $28 \mathrm{~km}$ にか けて低速度層が厚く存在していると解釈することができ る. Nakajima et al. (2001b) の結果では下部地殼がかな り低速度となっており, 本解析の結果と調和的である. しかしながら，コンラッド面の深さはZhao et al. (1990) の結果と一致していない. 本解析の結果と Nakajima et $a l$. (2001b) の結果のどちらにおいても, 下部地殼の速度 が遅いために，上部地殼と下部地殼での平均的な速度の 違いは小さくなっている.このような場合, Zhao et al. (1990) のように初動走時のみで推定されたコンラッド 面の深さは精度が悪くなってしまうと考えられる。

Nakajima et al. (2001b) では, KGJ の下の最上部マン トルが同じ深さにおける平均的な速度よりも低速度に
なっている. 彼らの与えたグリッドポイントは最上部マ ントルでは深さ $40 \mathrm{~km}$ と $65 \mathrm{~km}$ にしかないため, 見か け上厚い低速度域があるように見える（Fig. 7(d) で示し た範囲ではモ木面より下がすべて低速度域に対応）が, 本解析の結果は, 低速度域が深さ $42 \mathrm{~km}$ 付近にあり, その厚さは $5 \mathrm{~km}$ 程度であることを示唆している.

(5) SWU

深さ $35 \mathrm{~km}$ にモ木面と思われる速度ジャンプが見ら れ, Nakajima et al. (2001a), Zhao et al. (1990) の結果 と一致する (Fig. 7(e)). 深さ $11 \mathrm{~km}$ と $22 \mathrm{~km}$ にも速度 ジャンプが見られるあのの, Zhao et al. (1990) のコン ラッド面とは一致しない. しかし Nakajima et al. (2001 b) では深さ $10 \mathrm{~km}$ あたりで速度勾配が変化しており, その原因が本解析で見られる深さ $11 \mathrm{~km}$ の速度不連続 面ではないかと思われる，表層を除けば本解析の結果は 上部地殻で初期モデルよりも速く，下部地殼で遅くなっ ており, この傾向は Nakajima et al. (2001b) と調和的で ある.

データから得られたレシーバー関数 (Fig. 4) を見る と，時間原点の前に大きなしみだしが存在しており，こ の観測点付近では 3 次元的不均質性による散乱が強い と考えられる. 実際, 求められた構造む $20 \mathrm{~km}$ 程度以 浅で複雑となっている。このような強い散乱波と複雑な 構造は，この付近で地殼内 S 波反射面（ブライトスポッ ト）が多数見つかっている [堀・他 (1999)] ことと関連 すると思われる。

(6) HOJ

HOJ に関しては他の観測点と同じ初期モデル (Fig. 3) から始めると, Fig. 8(b) で見られるように, レシーバー 関数の時間原点にくるパルスがわずかに遅れている.こ れは表層が顕著な低速度層となっているためであると考 えられる. つまり, 表層の速度が遅い場合には入射角は 小さくなり, 水平動成分では直達 $\mathrm{P}$ 波の振幅は小さくな るが, 表層と基盤との境界面で大きな Ps 変換波が生じ, これは水平動に大きく現れるので, 水平動成分では直達 $\mathrm{P}$ 波より後にピークをむつパルスがつくられる．このよ うな場合, 水平動成分の最初のピークが上下動成分より 遅れてしまい, レシーバー関数のパルスが時間原点から ずれると考えられる. 実際, HOJ で観測されたもともと の地震波形を見てみると, 初動部分の水平動成分と上下 動成分とで立ち上がり時刻は等しいが，ピークの位置が ずれていることがわかった。 また, Iwasaki et al.(1999) の結果でも, HOJ 付近では地震波速度の遅い表層が存在 することが示されている.

この遅い表層による影響を見積もるため, Fig. 9(a)の 破線で示したように, 厚さ $5 \mathrm{~km}$ で $\mathrm{P}$ 波速度が $3.0 \mathrm{~km}$ 


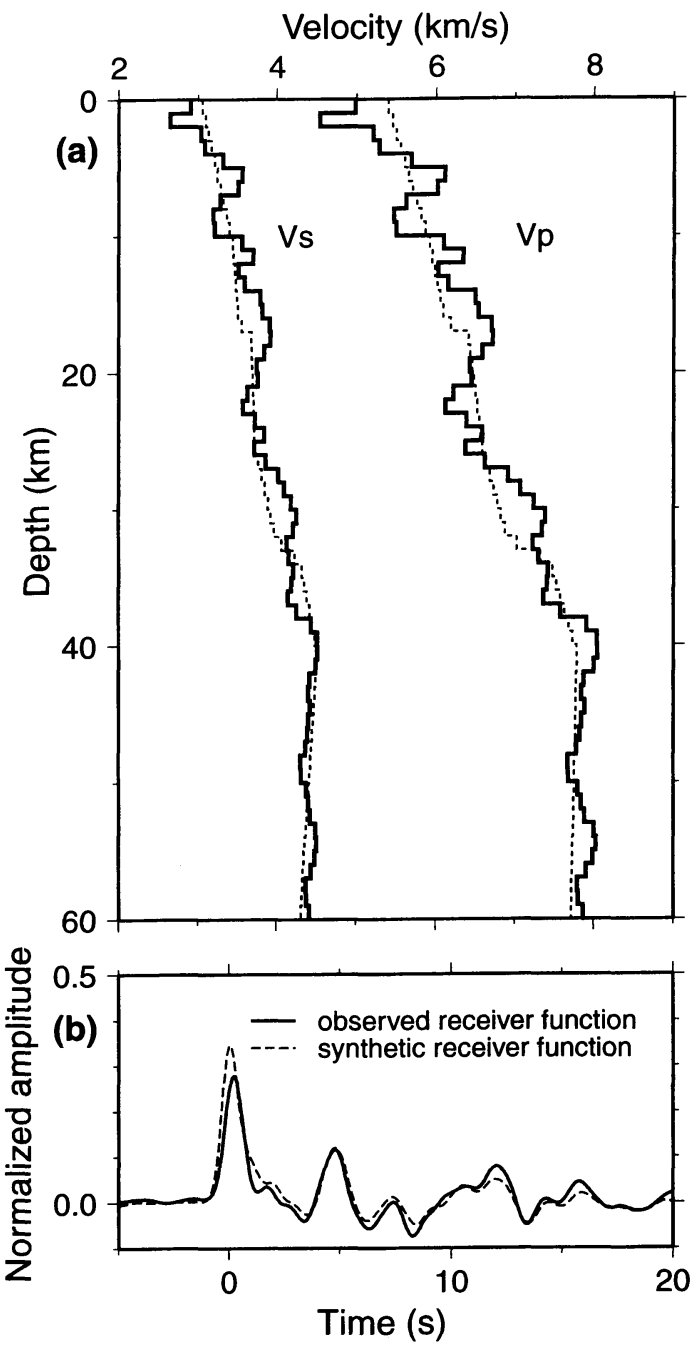

Fig. 8. (a) Velocity structure beneath HOJ (solid line) estimated by using the initial model shown in Fig. 3. Dashed line represents the structure estimated by Nakajima et al. (2001b). (b) Comparison of the observed receiver function (solid line) and synthetic (dashed line) calculated from the estimated structure indicated by solid line in Fig. 8(a).

から $5.7 \mathrm{~km} / \mathrm{s}$ に緩やかに変化する表層を初期モデルに 組み込んでインバージョンを行った. その結果, Fig. 9 (b) に示したようにレシーバー関数の時間原点のずれの ない解が得られた. しかし推定された速度ジャンプは Nakajima et al. (2001a) や Zhao et al. (1990) によるモ ホ面の深さ約 $32 \mathrm{~km}$ にはなく, 深さ $27 \mathrm{~km}$ 付近と 36 $\mathrm{km}$ 付近に見られる (Fig. 9(a)). 地震波速度加ら見ると, 深さ $36 \mathrm{~km}$ の不連続面がモホ面ということになる.し

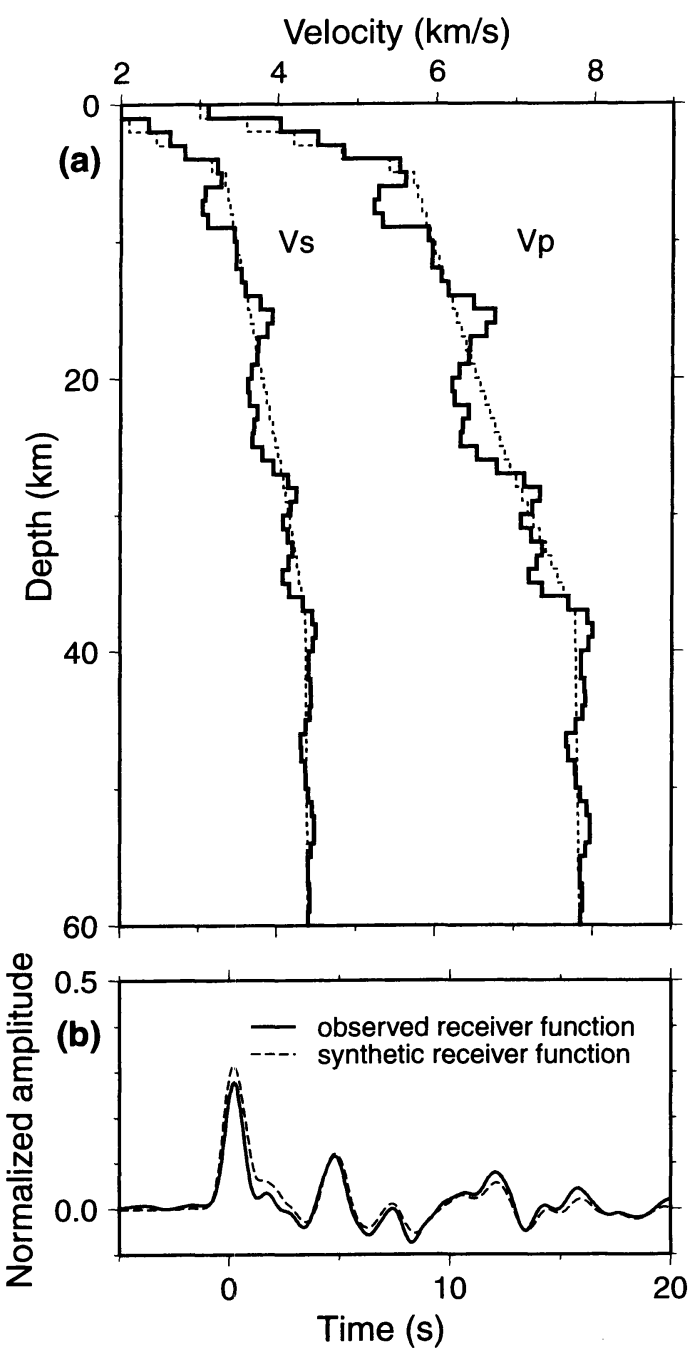

Fig. 9. (a) Velocity structure beneath HOJ (solid line) estimated by using the initial model (dashed line) that contains a low-velocity surface layer. (b) Comparison of the observed receiver function (solid line) and synthetic (dashed line) calculated from the estimated structure indicated by solid line in Fig. 9(a).

かしながら，このような低速度の表層が存在する場合， 表層での多重反射・変換に起因する大振幅の波とモ木面 からの変換波がほぼ同じ時刻に到着するため, モホ面の 深さと表層の構造がトレードオフし，モホ面は初期モデ ルに拘束されやすくなる，つまり，モホ面の深さの違い による波形の食い違いが生じても，表層の構造を微調整 することによって，レシーバー関数の観測值をうまく説 明する構造をつくることができるため，このような低速 度の表層が存在する場合には, レシーバー関数からモホ 
面の深さを精度良く推定することは困難である，一方， HOJ の下付近を反射点とするモホ面からの反射波が顕 著に見えている [Nakajima et al. (2001a)] という観測事 実を考慮すると，モホ面で速度コントラストが大きく なっている構造の方がもっともらしいと考えられる. Nakajima et al. (2001a) に従ってモ木面を深さ $32 \mathrm{~km}$ に置いた初期モデルを用いてインバージョンを行うと, モホ面はやはり深さ $32 \mathrm{~km}$ に求められるものの, その 速度コントラストは極めて小さくなった。 一方, Iwasaki et al. (1999) ではモホ面の深さを $28 \mathrm{~km}$ としてお り,この結果は Fig. 9 の結果とほぼ調和的であり, かつ 速度コントラストも大きくなっている，以上のことから HOJ の下ではモホ面の深さは $27 \mathrm{~km}$ とするのが妥当で あると考えられる.ただし，その場合，モホ面直下で 37 $\mathrm{km}$ 以浅に低速度域が存在することになるが，これが何 を示しているのかは不明であり, この低速度層の存在の 有無を含めて今後さらに検証を行う必要がある.

\section{2 東北日本弧の地殻・最上部マントル速度構造}

太平洋側の観測点である HSK, HMK, DIT では, コン ラッド面に対応すると思われる速度不連続面が深さ 20 $\mathrm{km}$ 付近に見られ，その位置は Zhao et al. (1990)の結 果とほぼ一致する. 一方, KGJ と HOJ では Zhao et al. (1990) の結果と一致するコンラッド面は見られないが, 深さ $15 \sim 17 \mathrm{~km}$ 付近に正の速度ジャンプが見られ，そ の数 $\mathrm{km}$ 下から低速度域となっている. SWUではコン ラッド面は不明瞭であるが，これはこの付近に多数の S 波反射面が見られることと関係すると思われる.

KGJ の下では深さ $16 \mathrm{~km}$ から $18 \mathrm{~km}$ にかけて高速 度層が見られる. 東北地方の地震は低周波微小地震を除 けば，ほとんどは深さ $15 \mathrm{~km}$ 以浅で発生する [Hasegawa and Yamamoto (1994)] が, KGJ の下では例外的 に深さ $15 \mathrm{~km}$ と $20 \mathrm{~km}$ に $M 4$ 級の地震が発生してい る [河野 (1993)].この例外的に深部で発生した地震の 震源の深さと, この高速度層の深さがほぼ一致している ことは興味深い.

Nakajima et al. (2001b) では, 下部地殼の地震波速度 が系統的にルーチン構造よりあ遅く求められている. 本 解析でもルーチン構造を基にしてっくった初期モデルに 拘束させる条件を与えているにもかかわらず, 下部地殼 が初期モデルよりも系統的に遅くなっている傾向が見ら れる.ただし，低速度域の中心の墚さは観測点によって 異なっている.

モホ面の深さは, 太平洋側の観測点では約 $30 \mathrm{~km} \mathrm{に}$ 求められ, 脊梁地域の SWUでは $34 \mathrm{~km}$ と深く求めら れた. 日本海側の観測点である HOJ については, Nakajima et al. (2001a) や Zhao et al. (1990)の結果よりモホ
面は浅い可能性がある. Zhao et al. (1990) では東北地方 全域のモホ面を滑らかな関数でつないでおり，このよう な場合, 一般に解析領域の端では信頼度は落ちる. HOJ は彼らの解析領域の端に位置するため, このような䛊差 が大きく影響している可能性がある. 一方, Nakajima et al. (2001a) ではこの付近のモ木面の推定に浅発地震 からの反射波を用いている。 むし, 東北大学の震源が真 の深さより系統的に深く震源決定されていれば, この手 法では, モ木面は真の深さより深く求められてしまう. したがって,このような系統的な震源のシフトが存在す るかぞうか, 今後検討する必要がある.

最上部マントルに関しては, DIT, KGJ で深さ $40 \mathrm{~km}$ から $50 \mathrm{~km}$ 付近に低速度層が見られ, 同様の傾向が SWUにあ見られる.これは Nakajima et al. (2001b) の 結果に見られる最上部マントルでの低速度域に対応して いるものと考えられ，本解析の結果は，これらの観測点 の下では, この低速度域の厚さが $5 \mathrm{~km}$ 程度であること を示している. ただし, 2.2 .3 節で述べたように, レシー バー関数による推定では, 有限の時間ウィンドーの影響 で, 深い領域ほど推定結果の信頼度は低下するため, 今 後さらに検討が必要であろう.

なお，本研究および過去のトモグラフィーの研究のい ずれにおいても，インバージョンに拘束条件が組み込ま れているため, 各層の速度の絶対值に関する比較は困難 ではあるが，2.4節で述べたように相対的特徴について は，ほぼ真実を表していると考えられる，コンラッド面 やモホ面の深さについては, Nakajima et al. (2001a) や Zhao et al. (1990) では各層の速度を固定しているため, 層内の不均質性を考慮すれば本研究と厳密に一致する必 然性はない. しかし, 彼らが仮定した各層の速度と本研 究の初期構造は, どちらも過去の研究で得られた東北地 方の平均的構造を元にしており，これは平均值としては 真実とそれほど大きく変わらないと考えられる. Zhao et al. (1990) の場合, 境界面の深さとトレードオフする のは基本的には各層の平均速度であり, その平均速度が 我々の初期構造や真の構造と矛盾しないため, ほぼ同様 の深さにコンラッド面やモホ面が求められたものと考え られる. また, Nakajima et al. (2001a)については, 太 平洋側のモホ面の位置は変換波を用いて推定しており, 本研究のレシーバー関数による推定も結局のところ変換 波を解析しているので, 各層の速度が極端に異ならない 限り, 両者の結果は一致するのが自然である. 違いが見 られたHOJの近傍については我々の結果むトモグラ フィーの研究結果も信頼度がやや劣るため, 今後, 慎重 に解析を行うことが重要である.レシーバー関数につい ては，表層の影響がモホ面の誤差となって現れているの 
で，今後，浅部構造探査によって表層を詳しく調べ，そ こで得られた結果に表層を固定してレシーバー関数解析 を行ったり，また，モホ面付近の情報を増やすため，よ り長いデータウィンドウを用いるなどの工夫が考えられ る.

本解析では，水平成層構造を仮定して解析を行った。 海岸線付近以外については，主要な境界面の傾斜はそれ ほど大きくないことがこれまでの研究によりわかってお り, HSK 観測点以外については, 傾斜層構造の影響は小 さいと考えられるが，今後様々な入射方向・入射角の波 を独立に取り扱って解析し，今回の結果を検証する必要 がある。

\section{§4. 結}

本解析では, レシーバー関数による速度構造推定にお いて, 従来の手法の問題点を指摘し，それを改善するた めに以下の方法を示した。

(1) 周波数領域でレシーバー関数を求める際の不安 定性に対する解決策として平滑化法を提案した。この方 法を適用することで，従来用いられているウォーターレ ベル法よりも信頼できるレシーバー関数を推定できると 考えられる.

(2) レシーバー関数のスタッキング手法として, 周波 数領域での重み付きスタック法を提示した。この方法を 用いることにより, $\mathrm{S} / \mathrm{N}$ の悪い周波数帯域が存在する波 形についても，有効利用することが可能になった。

(3) レシーバー関数を用いたインバージョンでは解 の一意性や絶対走時の問題がある.この問題を克服する ため, 過去の研究結果を先験的情報として取りいれて, 絶対走時も考慮したインバージョン法を提示した.

次に，上記の方法を用いて東北日本弧の地款・最上部 マントル速度構造の推定を行った。 得られた結果は以下 のとおりである.

(1) 太平洋側では，深さ $20 \mathrm{~km}$ 付近にコンラッド面 と思われる速度不連続面が見られる。これは Zhao et al. (1990) が示したコンラッド面の深さとほぼ一致してい る.また，モホ面の深さは，太平洋側で約 $30 \mathrm{~km}$, 脊梁 付近では $34 \mathrm{~km}$ と深くなり, Nakajima et al. (2001a) やZhao et al. (1990) の結果とほぼ一致する. 一方, 脊梁 付近では, コンラッド面が不明瞭で地震波の散乱が強い ことから，この付近の不均質性が強いことが示唆され る.

(2) HSK と DIT の下の下部地款内に顕著な低速度層 が見いだされた。この領域では Nakajima et al. (2001b) でも下部地款における速度の逆転が見られる。この低速 度層の深さは Nakajima et al. (2001b) では精度良く求
められないが, 本解析によって, HSKについてはコン ラッド面直下，DITについてはモホ面直上に位置してい ることが示された。

(3) KGJについては, 深さ $40 \mathrm{~km}$ 付近に低速度層が 見られる. Nakajima et al. (2001b) でも深さ $40 \mathrm{~km}$ 付 近に低速度域が推定されているが，その厚さは良く求め られていない．本解析の結果は，この低速度層の厚さが $5 \mathrm{~km}$ 程度であるごとを示唆している.

(4) HOJ 直下では, 極めて遅い表層が存在している. これは Iwasaki et al. (1999) の結果と一致する. また HOJ 直下では，モホ面の深さを精度良く求めることがで きなかったが, Iwasaki et al. (1999) と同様に深さ 27 $\mathrm{km}$ の不連続面がモホ面であるとすれば，そのモホ面の 下から深さ $37 \mathrm{~km}$ 程度までは低速度層となっている可 能性がある。

\section{謝辞}

本研究の解析において, セントルイス大学の Charles J. Ammon 博士から, レシーバー関数のインバージョ ン・ソフトゥェアを提供していただいた。 広帯域地震波 形のデータ収録システムについては東京大学の鷹野 澄 博士らによる ERIOS システムのソフトウェアを使わせ ていただいた．東北大学の中道治久博士（現東京大学） からは, レシーバー関数解析に関する有益なご助言を頂 戴した。 また，京都大学の中西一郎博士，加藤 護博士 と匿名の查読者からは, 論文の改善に非常に役立つ多く のご助言をいただいた，作図においては，八ワイ大学の Paul Wessel 博士と米国国立海洋大気局（NOAA）の Walter H. F. Smith 博士による GMT を使わせていただ いた.これらの方々に厚く御礼申し上げる.

\section{文献}

Abers, G. A., 1998, Array measurements of phases used in receiver-function calculations: importance of scattering, Bull. Seismol. Soc. Am., 88, 313-318.

Ammon, C. J., 1991, The isolation of receiver effects from teleseismic $\mathrm{P}$ waveforms, Bull. Seism. Soc Am., 81, 2504-2510.

Ammon, C. J., G. E. Randall and G. Zandt, 1990, On the nonuniqueness of receiver function inversions J. Geophys. Res., 95, 15303-15318.

Cassidy, J. F., 1992, Numerical experiments in broadband receiver function analysis, Bull. Seism. Soc Am., 82, 1453-1474.

Clayton, R. W. and R. A. Wiggins, 1976, Source shape estimation and deconvolution of teleseismic body waves, Geophys. J. R. Astr. Soc., 47, 151-177.

Hasegawa, A., N. Umino and A. Takagi, 1978, Doubleplaned structure of the deep seismic zone in the 
northeastern Japan arc, Tectonophysics, 47, 43-58.

Hasegawa, A. and A. Yamamoto, 1994, Deep, lowfrequency microearthquakes in or around seismic low-velocity zones beneath active volcanoes in northeastern Japan, Tectonophysics, 233, 233-252.

Hasemi, A. H., H. Ishii and A. Takagi, 1984, Fine structure beneath the Tohoku district, northeastern Japan arc, as derived by an inversion of P-wave arrival times from local earthquakes, Tectonophysics, 101, 245-265.

日野幹雄, 1977 , スペクトル解析, 朝倉書店, $300 \mathrm{pp}$.

堀 修一郎・海野徳仁・浅野陽一・長谷川 昭, 1999, 東北日本の $\mathrm{S}$ 波反射面, 日本地震学会講演予稿集, $\mathrm{P}$ 140.

Horiuchi, S., A. Yamamoto, S. Ueki, K. Tachibana, T. Kono and A. Takagi, 1982, Two-dimensional depth structure of the crust beneath the Tohoku District, the northeastern Japan arc, Part II. Moho discontinuity and P-wave velocity, J. Phys. Earth, 30, 7186.

Iwasaki, T., T. Yoshii, T. Moriya, A. Kobayashi, M. Nishiwaki, T. Tsutsui, T. Iidaka, A. Ikami and T. Masuda, 1994, Precise P and S wave velocity structures in the Kitakami massif, Northern Honshu, Japan, from a seismic refraction experiment, J. Geophys. Res., 99, 22187-22204.

Iwasaki, T., T. Takeda, W. Kato, S. Sekine, H. Sato, N. Hirata, T. Moriya, N. Umino, T. Okada, A. Hasemi, K. Miyashita, T. Mizogami, K. Tashiro, T. Matsushima and H. Miyamachi, 1999, Extensional deformation recorded in wide angle reflection profile across Northern Honshu, Japan, Eos Trans. AGU, 80, Fall Meet. Suppl., F1040.

Jackson, D. D. and M. Matsu'ura, 1985, A bayesian approach to nonlinear inversion, J. Geophys. Res., 90, 581-591.

Jordan, T. H. and S. A. Sipkin, 1977, Estimation of the attenuation operator for multiple ScS waves, Geophys. Res. Lett., 4, 167-170.

Kennett, B. L. N., 1991, IASPEI 1991 seismological tables, Research School of Earth Sciences, Australian National University, Canberra, $167 \mathrm{pp}$.

河野俊夫, 1993, 北上山地の地震活動 (その 3), 地震火 山観測技術研究報告, 23, 34-49.

Langston, C. A., 1979, Structure under Mount Rainier, Washington, inferred from teleseismic body waves, J. Geophys. Res., 84, 4749-4762.

Li, X., R. Kind, K. Priestley, S. V. Sobolev, F. Tilmann, X. Yuan and M. Weber, 2000, Mapping the Hawaiian plume conduit with converted seismic waves, Nature, 405, 938-941.

Ludwig, J. W., J. E. Nafe and C. L. Drake, 1970, Seismic refraction, in "The Sea, Vol. 4, Part I", ed. by A. E. Maxwell, Wiley-Interscience, New York, 53-84.

松澤 暢, 1989, 後続波から推定される沈み込みプレー 卜境界の地震波速度構造の推定, 地震 $2,42,525-$ 536.
中島淳一・松澤 暢 - 長谷川 昭 - 趙 大鵬, 2001, 東 北日本弧の三次元地震波速度構造と $\mathrm{Vp} / \mathrm{Vs}$ 構造, 地 震研究所彙報, 76, 13-21.

Nakajima, J., T. Matsuzawa and A. Hasegawa, 2001a, Moho depth variation in the central part of northeastern Japan estimated from reflected and converted waves, Phys. Earth Planet. Int., submitted.

Nakajima, J., T. Matsuzawa, A. Hasegawa and D. Zhao, 2001b, Three-dimensional structure of $\mathrm{Vp}$, $\mathrm{Vs}$ and $\mathrm{Vp} / \mathrm{Vs}$ beneath northeastern Japan: Implications for arc magmatism and fluids, J. Geophys. Res., in press.

Nakajima, J., T. Matsuzawa, A. Hasegawa and D. Zhao, 2001c, Seismic imaging of arc magma and fluids under the central part of northeastern Japan, Tectonophysics, in press.

小原一成・長谷川 昭・高木章雄, 1986 , 東北日本弧に おける地款・上部マントルの三次元 $\mathrm{P}$ 波および $\mathrm{S}$ 波 速度構造, 地震 $2,30,201-215$.

大崎順彦, 1976, 地震動のスペクトル解析入門, 鹿島出 版会, 260 pp.

Owens, T. J., G. Zandt and S. R. Taylor, 1984, Seismic evidence for an ancient rift beneath the Cumberland Plateau, Tennessee: a detailed analysis of broadband teleseismic P-waveforms, J. Geophys. Res., 89, 7783-7795.

Park, J. and V. Levin, 2000, Receiver functions from multiple-taper spectral correlation estimates, Bull. Seism. Soc. Am., 90, 1507-1520.

Peng, X. and E. D. Humphreys, 1998, Crustal velocity structure across the eastern Snake River Plain and the Yellowstone swell, J. Geophys. Res., 103, 71717186.

Pisarenko, V.F., 1970, Statistical estimates of amplitude and phase corrections, Geophys. J. Roy. Astr. Soc., 20, 89-98.

Randall, G. E., 1989, Efficient calculation of differential seismograms for lithospheric receiver functions, Geophys. J. Int., 99, 469-481.

Research Group for Explosion Seismology, 1977, Regionality of upper mantle around northeastern Japan as derived from explosion seismic observations and its seismological implications, Tectonophysics, 37, 117-130.

Shibutani, T., M. Sambridge and B. Kennett, 1996, Genetic algorithm inversion for receiver functions with application to crust and uppermost mantle structure beneath Eastern Australia, Geophys. Res. Lett., 23, 1829-1832.

鷹野 澄・武尾 実・高橋正義・阿部勝征, 1989, 広帯 域地震計データの遠隔収集システム, 地震学会講演予 稿集, no. 2, 254.

Wessel, P. and W. H. F. Smith, 1995, New version of the Generic Mapping Tools released, EOS Trans. AGU, 76, 329.

Zhao, D., S. Horiuchi and A. Hasegawa, 1990, 3-D seismic velocity structure of the crust and upper 
mantle in the northeastern Japan Arc, Tectonophysics, 181, 135-149.

Zhao, D., A. Hasegawa and S. Horiuchi, 1992, Tomographic imaging of $\mathrm{P}$ and $\mathrm{S}$ wave velocity structure beneath northeastern Japan, J. Geophys. Res.,
97, 19909-19928.

Zhu, L. and H. Kanamori, 2000, Moho depth variation in southern California from teleseismic receiver functions, J. Geophys. Res., 105, 2969-2980. 